\title{
The dangers of travel - Banditry on the roads in the old days
}

Authors' Contribution: A Study Design B Data Collection

C Statistical Analysis

D Data Inte

E Manuscript Preparation

F Literature Search

G Funds Collection

\author{
Piotr Godlewski1 ABCDEF , Dariusz T. Skalski ${ }^{2}$ ABCDEF, Robert Mruczyk 3 ABCDEF \\ ${ }^{1}$ Gdansk University of Physical Education and Sport, Gdansk, Poland \\ 2 State Higher Vocational School in Walcz, Poland \\ ${ }^{3}$ Marshal Jozef Pilsudski Higher School of Safety and Security Services in Warsaw, \\ Poland
}

\section{abstract}

Background: Both in the most distant history and nowadays, travel is accompanied by danger. Nowadays, insecurity is becoming a basic barrier to tourist travel to high-risk areas. The aim of the study was to make a comparative review related to the subject of travel danger in retrospective terms.

Material and methods:

In a scholarly review, the authors mainly used the historical method, the method of establishing historical facts, the comparative method. The method of analysis and criticism of literature was also used.

Results: Travel safety is not a common topic of historical literature on tourism. Although we have many fragmentary accounts in the diary literature, in Polish historiography there are no scholarly monographic works and articles that put the subject of travel safety in a historical context.

Conclusions: Travel has always been accompanied by danger. Nowadays, insecurity is becoming a basic barrier to tourist travel to high-risk areas. Threats on the road are of a difficult nature to predict, from the dangers caused by the forces of nature to the deadly threat resulting from human actions, most often with an intent to rob, but also against a political (terrorism), religious or national background. Despite the ongoing civilizational changes, including the extraordinary dynamics of cultural changes, the dangers of travel still show an analogy to the former days. The end of the nineteenth century was a borderline period, it marked the irretrievable end of primitive road banditry. The development of safe communication, the emergence of strong state bodies in Europe with a developed system of security apparatus effectively limited and then eliminated the epicentres of high-risk areas, which does not mean the complete elimination of road banditry. Also today, information about attacks on tourists is coming from some regions of Europe, the mechanisms and methods are confusingly similar to those known from history.

Key words: history of tourism, culture tourism, danger of travelling.

\section{article details}

Article statistics: Word count: 11,625; Tables: 0; Figures: 0; References: 42

Full-text PDF: http://www.balticsportscience.com

Copyright $\odot$ Gdansk University of Physical Education and Sport, Poland

Indexation: Celdes, Clarivate Analytics Emerging Sources Citation Index (ESCI), CNKI Scholar (China National Knowledge Infrastructure), CNPIEC, DOAJ, EBSCO - Central \& Eastern European Academic Source, EBSCO - SPORTDiscus, EBSCO Discovery Service, Google Scholar, Index Copernicus, J-Gate, Naviga (Softweco, Primo Central (ExLibris), ProQuest - Family Health, ProQuest - Health \& Medical Complete, ProQuest - Illustrata: Health Sciences, ProQuest Nursing \& Allied Health Source, Summon (Serials Solutions/ProQuest, TDOne (TDNet), Ulrich's Periodicals Directory/ ulrichsweb, WorldCat (OCLC)

Funding: This research received no specific grant from any funding agency in the public, commercial, or not-for-profit sectors. Authors have declared that no competing interest exists. Piotr Godlewski; Gdansk University of Physical Education and Sport; email: piotr.godlewski@awf.gda.pl

is is an open access article distributed under the terms of the Creative Commons Attribution-Non-Commercial-NoDerivatives 4.0 International (https://creativecommons.org/licenses/by-nc-nd/4.0/), which permits use, distribution, and reproduction in any medium, provided the original work is properly cited, the use is non-commercial and is otherwise in compliance with the license. 


\section{INTRODUCTION}

According to the German sociologist H. J. Knebel, author of perhaps the first sociological book on tourism, a tourist is: "a person travelling during a holiday, for leisure and pleasure". He defines tourism as "the pressure of mobility", the existence or absence of social relations with the locals, "satisfying the need for luxury through means obtained in the place of permanent residence" and "striving for comfort and physical security" [1:6]. One of old guidebooks suggesting advantageous travelling, De arte Peregrinandi, reads: "travel is the difficulty of seeing and exploring foreign lands, and this effort will not suit just anyone" [2:138].

Since the dawn of time, one of the fundamental barriers to travel has been the fear of leaving a well-known, "tame" place of life and ventilating into a foreign space, most often perceived as hostile and dangerous [3:139].

Despite the dangers of travel for thousands of years, almost since the dawn of human civilization, some atavistic and archetypal force of new knowledge, beyond the conditions of being, has prompted people to change their place of residence, to move, to wander around the world [4]. Travellers, who will later be called tourists, choose the safest possible roads, more willingly where there were hospitable, friendly parties and good people. Routes leading among dangerous and sinister areas were reluctantly chosen. And it seems that the danger of travel in the twenty-first and subsequent centuries will still accompany tourist travellers, because the world is shaken by various dramatic events that limit carefree travel. And the spectre of further pandemics can limit this movement to a minimum [5:9].

In the Middle Ages, millions of pilgrims, tourist travellers, merchants, soldiers, students, vagabonds, etc. travelled throughout Western Europe along a miserable and dangerous road network. They often suffered from the inconveniences of travel, hunger and thirst, endured cold and heat, the malice of carriers, the dishonesty of guides, and the deception of innkeepers. They were exposed to the dangers of travel, loss of life and limbs. In the Middle Ages, it was mainly merchants and pilgrims that travelled. The purpose of the peregrination were mostly places of religious worship, as well as famous colleges universities of Italy, universities in Padua and Bologna. Travelling tourists visited Rome or Santiago de Compostela, Aachen, Canterbury or Einsiedeln. Many continued on their long journey to Jerusalem. Since the sixteenth century, a high dynamics of travel has been observed in Europe. The travel movement included the youth of France, Spain and Italy. For educational purposes, young German aristocrats were sent, and soon they were joined by sons of Danish and Swedish nobility.

However, a typical tourist trip appeared only in the sixteenth century. At that time, it became fashionable for rich people, mainly aristocracy, to send young people on a journey through Western Europe. The main motive of these trips was to get to know the culture of the developed countries of Europe, often to undertake university studies. Around 1667, educational journeys held in the sixteenth and seventeenth centuries were referred to as the Grand Tour. Like the entire everyday life of the inhabitants of Europe, travel since the times of the Grand Tour has undergone a continuous evolution in accordance with the rhythm of civilizational development. In particular, Christianity became the driving force for prototourism. Religious ideology, mysticism, simple curiosity have caused that from the early Middle Ages to the present day, these motifs have catalysed the trend of travel to places of religious worship.

Crime and the standard of socio-economic living have always had a feedback loop. And so, the overall crime rate increased in the sixteenth century, and then decreased after the mid-sixteenth century. The reason may have been the harvest in the last decades of the sixteenth century, as well as slower population growth and greater availability of work. 
A sharp increase in robberies usually occurred after a poor harvest, or after the end of the war, when demobilized soldiers returned home, and the roads were full of armed and organized in bands of stragglers. Sometimes it was during wars that crime declines were observed.

Both in the Middle Ages and the following sixteenth and seventeenth centuries, theft and violence were the main manifestations of crime. Travellers were usually robbed of small sums of money or goods, such as food. Violent and life-threatening crimes against travellers were a minority of cases. When, as a result of the spread of literacy, the availability of printed information about crimes increased, and often exaggerated their number for populist sensationalism, the public became mistaken about the increase in crime. In the nineteenth and twentieth centuries and at the beginning of the twentieth century, crime declined, as it did after 1850 [6].

In antiquity and in the Middle Ages, Europe formed a comprehensive territory, the borders of which did not constitute a barrier to the movement of travellers. The barrier was the hardships of travel and the risks lurking on the roads. It must be remembered, however, that people in ancient times were accustomed to uncertainty, because in turbulent times it was impossible to avoid dangers. Danger was, therefore, an inseparable companion of everyday life on the journey. Most often they wandered on foot, often also on horseback. To carry large luggage, pack animals were used. Between the eleventh and twelfth centuries, the common use of the horse collar and horseshoe began, the carts already had four wheels, which allowed them to carry a greater weight [7:117].

\section{MATERIAL AND METHODS}

The safety of travel has not become a particularly emphasized topic of historical tourist literature, both in the past and in the present. Although we have many fragmentary accounts in the diary literature, there are no scholarly monographs in Polish historiography that would capture the safety of travel in the historical context. It seems that in the twentyfirst century, in view of global terrorism, learning about the dangers of travel in ancient times can serve the modern reception.

Although the problem of the danger of travel, and later of tourist travel, is an interesting issue, for a long time it did not have adequate historiography or studies of contemporary problems related to it. As Andrzej Stasiak writes, the researchers primarily focused on the positive aspects of tourism development and the resulting economic, social, cultural benefits, etc. and even that only with time, in the 1990s [5]. In the twentieth century, other negative phenomena occurring in tourist reception areas began to be studied, including inter alia the impact of crime, wars and terrorism on the tourism sector [8:16], [10:416456]. It seems that the catalyst for more intensive scholarly literature in this area could be the global events related to the terrorist attack of 11 September, 2001 in the USA, as well as the tragic attacks of Al-Qaeda in various parts of the world. The development of the Islamic State (ISIS) and, consequently, the launch of a global war on terrorism has become the cause of greater interest of scientists in the problem of the impact of the terrorist threat on the development of tourism.

From the point of view of the presented paper, it is more important to determine the state of the literature on the issue of travel safety in a retrospective context. Already at the beginning of the nineteenth century, there was literature about bandits and robbers. Among the published books, which at that time had a literary character, although not devoid of extensive factography, one should mention the biography of Rob Roy by Walter Scott (1818). 
Scott, author of historical novels, carefully reconstructs the era and its scenery in order to place his hero and eighteenth-century Scotland and England against the background of socio-political conflicts and the economic situation. Another novel by Scott containing criminal motifs was the book Ivanhoe published in 1820 (Polish edition 1821). It was another historical novel by Walter Scott. The action of this novel takes place in twelfthcentury England. Its main character is an Anglo-Saxon knight Wilfred of Ivanhoe, and the action takes place in the times of Norman-dominated England in the vicinity of southern Yorkshire and northern Nottinghamshire. One of the main characters of the book was the legendary outlaw, Locksley - Robin Hood, the leader of a forest gang.

In 1824, The Newgate Calendar was published by Andrew Knapp and William Baldwin. Originally, it was a monthly newsletter about executions, containing biographical notes of notorious criminals such as Sawney Bean, Dick Turpin, John Wilkes or Moll Cutpurse. Collective editions of these texts began to appear in the mid-eighteenth century, and in 1774 a five-volume edition became the standard. The Newgate Calendar is a strange and gruesomely detailed mix of fact and sensational fiction [10]. In the 1830s, there was a great demand for cheap fiction for the intelligentsia and also for the proletariat. It should be noted that literacy was becoming popular among workers. In England, by 1830, as many as three-quarters of workers had learned to read. Edward Lloyd was a pioneer of cheap sensational popular literature. His Penny Bloods was a great success, especially among the working class. From 1835 he published such titles as Lives of the Most Notorious Highwaymen, Paws, and History of the Pirates of All Nations.

The subject of robberies was also a material for artists and poets. The theme of bandits in Spain attacking travellers on the routes was a motif in the work of Francisco José de Goya. An example is the depiction of a bloody attack on a stagecoach (Asalto al coche from 1787 and Asalto de ladrones from 1793-1794), as well as a series of paintings depicting the Franciscan Pedro de Zaldivia disarming the bandit El Maragato (dated 1806-1807). Unusual in its dramaturgy and mood is also attributed to Goya cycle "bandit attack" (Asalto de bandidos) dating back to the years 1808-1812. In it, the artist depicts drastic scenes of looting, rape and murder, as well as being shot by hostage bandits.

The aim of this study is to make a comparative review related to the subject of travel danger in retrospective terms. The work has the character of scholarly reconnaissance and touches on selected historical threads related to banditry on the roads in the old days. In their scholarly analysis, the authors mainly used the historical method as well as the method of estab-lishing historical facts through induction and deduction. In the development of the historical narrative, a comparative method was used. In addition, the method of analysis and criticism of literature was used to present various concepts of presenting the history of banditry on the roads in retrospective terms in the literature on the subject.

\section{TRAVEL DANGERS - ROBBERY, ROBBERY, ROBBERY}

In ancient times, it was it was the Balkan Peninsula, the Rhineland, Dalmatia and Spain that were particularly dangerous. A high intensity of attacks was recorded especially in Asia Minor [11]. From this period come the tombstones of Roman travellers who died as a result of a bandit attack. The Grossglockner Hochalpenstrasse, climbing to the altitude of 2,504 m above sea level in a place called Hochtor was a frequented route already in Roman times. In the Middle Ages, it was overrun by gangs of villains and robbers who robbed in the summer and hid in the higher parts of the mountains in the winter. Already in the time of Charlemagne, the Alps were an excellent hiding place for all sorts of villains. In 886, a clergyman-robber from the town of St. Moritz with an armed detachment blocked the road between the Jura and the St. Bernardine Pass, preventing the march of Lothar's 
troops. In antiquity and in the early Middle Ages, people travelled almost exclusively during the day, trying to gather in clusters for safety. However, the joint journey with strangers was risky, as it might turn out that among the wanderers there were various shady-looking individuals of the wrong sort. In the 12th-13th centuries, maps were hardly ever used, and those that were showed the area in a very simplified way. Travellers also often wandered, deviated from the road, wandering around the area for hours and then returning to the same place. Already in antiquity, the real scourge of travellers were customs offi-ers. In the times to come this vicious profession spread horrendously.

Not only were there a wealth of common villains, but on the roads of medieval Europe there were also knights-robbers called raubritter. Among the demoralized knights, many were of noble birth, with a strongly developed sense of belonging to Christianity, but this did not prevent them from looting and robberies on the tracts. All this was within the mental and social directive of the law of the strongest. After all, in feudal times, the armed acquisition of goods by force was something normal. S. Milewski draws attention to this matter, quoting N. Elias: "the overwhelming majority of the members of the secular upper class in the Middle Ages had the lives of gang leaders. They were characterised by the customs and preferences proper to the rogue ring leaders" [12:48]. Knights often came from old-established families; they permanently stayed in castles, despised any labour, especially in the field, and their profession became rob-bery, attacks on merchants and travellers passing near their castle. A special plague of raubritters was observed in Germany, where the number of knights-robbers was very significant. Groups of raubritters organised themselves into gangs, with the greatest intensity of this practice found in the mountainous areas of Bavaria, Tyrol, Italy, Scotland, and in Poland in Silesia.

In the twelfth century, knights showed up, recruiting mainly from the plebs, in the poorest and most densely populated lands of Western Europe, such as: Wales, Braband, Flanders, Aragon, Navarre. These itinerant soldiers, also called routiers ${ }^{1}$ or cottereaux, organised themselves in gangs that were difficult to defeat. The routiers were particularly dangerous in times of peace, when they were left without pay and engaged in outright robbery. When their activities paralysed trade and the movement of travellers, round-ups involving large military forces were organized on them. The apprehended were treated cruelly. Richard the Lionheart ordered in 1182 to kill half of the disarmed gang of Brabants, and the rest to be released earlier, ordering their eyes to be gouged out [13:362-363].

In France, in the time of Philip Augustus, degenerate knights became a real scourge. A. Luchaire, an historian who studies the daily life of thirteenth-century France, writes of one of them: "His life descends on plunder, on the plundering of churches, on attacks on pilgrims, on the oppression of widows and orphans. He finds a special delight in the mutilation of the inno-cent" [14:275]. It seems that robbery was at that time a phenomenon typical of the entire layer of chivalry, with the possible exception of the narrow elite. This phenomenon was typical of the whole of Europe also in later centuries.

The fodder for banditry in the fourteenth and fifteenth centuries was the endless time of wars, riots and tumults. According to A. Huizing, "War that was becoming a chronic phenomenon, the constant anxiety that various dangerous gangs stirring up in the cities and throughout the country, the eternal threat of hard and uncertain justice ... [all these were] the fodder medium on which the sense of general uncertainty grew" [15:51].

1 They were mercenary soldiers of the Middle Ages. Their special distinction from other paid soldiers of the time was that they were organised in bands (routes). The term was first used in the twelfth century, but it is particular-ly associated with the free companies that terrorised the French countryside during the Hundred Years' War. Many different terms were used to describe these soldiers, some geographical (e.g. Brabançons of Brabant, Ar-agones of Aragon, Bascoli of the Basque Country) and other nicknames (e.g. cotereaux or cotereli, perhaps from the knife they were carrying). The background of their plunder was the Hundred Years' War, which lasted from 1337 to 1453. 
In the sixteenth century, the roads and forests of all Europe were full of wandering suspicious characters. The aforementioned state of war resulted in the relaxation of the central authority, an excess of the army with a plague of stragglers and deserters. There were years when travelling even a short distance required a lot of desperation. Robert Ascham, a Cambridge scholar who travelled around the Netherlands and Germany in the mid-sixteenth century, notes that near Cologne and Aachen, the forests were full of wellarmed villains [16:186].

In the seventeenth century, there were many dangerous places in Europe. A. Mączak writes that frequent robberies of travellers took place within a wide strip along the shores of the Mediterranean, starting from Catalonia to the Ligurian Gulf, Calabria, Campania, the Adriatic coast, then Lorraine, the mountainous and forested lands of central Germany, especially Spessart, where due to the poverty prevailing in that area, packs of robbers formed. Areas of particular risk were mainly mountainous and forested areas of the borderland, many gangs also prowled in areas around large urban centres. Mączak reports that the lands on the outs of the State of the Church and the Kingdom of Naples, France and Savoy, France and Spain were especially convenient for bandits. There were also zones of particular risk, for example, in the sixteenth and seventeenth centuries the road leading to Paris. The Balkans were also dangerous. In the mountain villages in the Stara Planina range, a massif of southern Bulgaria under a hundred years of Turkish occupation, numerous armed highlanders and robbers gathered in inacces-sible hiding places, in caves and ravines, organizing themselves into regular bands [17].

After the English Civil War in the mid-1640s, outlawed royalist officers armed with fire-arms, who were not familiar with trade and had no profession, remained unemployed. Their only professional skill was the ability to use weapons and fight. Being in desperation, military skills were used for criminal activities. From about 1650 to the turn of the nineteenth and twen-tieth centuries it was commonly said that there were as many bandits as crows. There was also a widespread fear of being on the road alone due to frequent attacks on travellers. The danger was so great that many travellers wrote wills before embarking on a long and dangerous journey.

In England, the image of a gentleman robber was created, and indeed some of the criminals came from wealthy backgrounds. Lady Katherine Ferrers, the wife of Sir Thomas Fanshaw, was a robber of an aristocratic family. Apparently, after dinner at their home, Lady Ferrers appeared in a robber costume, after which she robbed her guests. A certain Sir Humphrey Kynaston came from a privileged stratum, but after his estate fell into disrepair, he became a bandit and began to attack travellers. He was an exception among criminals because he shared the looted spoils with the poor, receiving food, shelter and protection in return. Perhaps because of this, he was never captured. However, the vast majority were degenerate violent criminals. Murder and sexual assault were common during robberies. The most famous robber in England at the time was Dick Turpin. He was a ruthless bandit who was active in a gang in the areas north of London. He was a member of the Essex Gang, later working with the famous robber Tom King, with whom he carried out robberies from his hideout in Epping Forest, and then hid in Yorkshire under the name John Palmer. In 1738 he was arrested, tried and hanged for stealing horses in April 1739.

The law against the perpetrators of violent assault was harsh, the penalty was death; culprits would mostly go to the gallows. The effectiveness of the fight against road banditry was facilitated by the repetitive pistol used by the police, as well as the continuous upgrading of po-lice methods, especially the creation of a mounted patrol around London in 1805 and the establishment of the Metropolitan Police in 1829. The last major gang, the Hanham and Cockroad gang, was stopped by a police sergeant in 1850 [18]. 
Great danger was imminent not only during the journey on the road, but also during the stay at an inn, at the resting place and overnight. It was impossible to trust the innkeepers in the middle of no way and the carriers. Especially the motif of the "red inn" aroused the fear in solo travellers or in small groups. As a symbol of a dangerous inn from the sixteenth century, the inn at Straslund was mentioned, where eight hundred guests were to fall victim. The horror of this story was that the body parts of these unfortunates were supposedly eaten marinated by next guests to come! Theophilus Gautier (1811-72), a French poet recalls an unpleasant experience with an innkeeper in Spain. The innkeepers with whom he stayed with the appearance of gal-lows birds: "Convinced that we did not understand Spanish, they asked our eskopeter if it would not be possible to rob us a few miles away. José Maria's former accomplice replied with a noble and dignified expression: «I will not allow this to happen, these young men are in my company: they are expecting an assault and have only on them as much as necessary for the journey, and the remainder of the money in the bills of exchange in Seville. Besides, both are tall and strong; as for the mine official, he is my friend, and in the galley we have four shotgun ». This convincing argument appealed to reason to the host and his assistants, who this time confined themselves to a simple robbery, permitted to the innkeepers of all countries" [19:234].

Damage to health or life could be caused in the robbery by marauding bandits, brabants, thugs, as well as marauder soldiers or deserters. One of the descriptions of travel quoted by A. Mączak gives us a view of the scale of dangers and reactions of contemporary travellers. Young traveller artist, Nicholas Stone relates: “On Tuesday morning (around eleven o'clock) we rode eighteen horses to go to Lyon. In the company there were two Jesuits from Paris and the captain of the ship of the King of the French, as well as others from very good company. A little before the night we met some riders, but they saw us so strong and did not commit rape (but then we heard that the same company attacked the carriage going to Lyon). Another time on this road we met and passed infantry troops of the French and Swiss, because we were well armed and strong, we drove without danger" [16:180].

Especially diaries and travel descriptions include numerous stories about robbers. Erik Dahlbergh, who travelled around Europe in the mid-seventeenth century, mentions the attacks he suffered in the years 1654-1655. He was particularly impressed by the attack at Mount Vesuvius near Torre del Greco, when the wandering Swedes were attacked by a gang of 16 people, robbed, undressed, and finally severely beaten. However, this was not the end of the Swedes' experience, because on the border between the Kingdom of Naples and the State of the Church they were attacked by forty bandits. However, they managed to buy out of the oppression, giving the attackers ten doubloons (about 36 thalers) [16:186].

The notorious robbers were Lisowczyks, fearless mercenary soldiers. The Lisowczyk detachment was organized at the beginning in 1614 by a certain "Polish Rider", Aleksander Józef Lisowski, notorious for his plunder, arbitrariness and cruelty. The regiment at various times numbered from 2 to 20 thousand soldiers. For more than twenty-two years, they aroused horror among the population of the areas where they fought and were stationed. The immortality of the Lisowczyks was brought to the fame of the Lisowczyk attributed to Rembrandt. The Lisowczyks were a formation consisting of outcasts and plebeians, including criminals. The lack of hostilities, in the situation of unpaid remuneration, deprived professional soldiers of their livelihood, hence for long periods they supported themselves from robberies and looting.

Often, state guards and thugs acted together and in collusion. One such case is described by Lady Anna Fanshawe, the wife of an English royalist during the English Civil War (the 
1640s). During a trip to Abbeville, the local governor advised the lady to take protection be-cause of the threat of bandit assaults in that area. During the journey, Lady Fanshawe met 50 well-armed riders who passed travellers at a safe distance. It turns out that they cooperate with security soldiers. One of them says bluntly: "Lady, we are all from one company and we are standing in this city" [16:187].

The problem of soldiers attacking and robbing travellers was also given in the description of the journey of Prince Władysław Waza. The chronicler of the journey, S. Pac writes that in the vicinity of Brussels on the local roads it was very dangerous due to the large number of wandering Spanish and Dutch troops: "Of these soldiers in a few dozen, in a hundred and sometimes more people, both cavalry and infantry, falls on the roads and on the other places that have no defence, fishing from one side and on the other, this is the Olendra of the Spaniards and the Spaniards of the Olenders. (...) Therefore, the soldiership or the part that is more playful from the company, having separated when the merchant-li, foreigner-li are destroyed on the road, and this happens very often, is lost, so there are always enough abdanked in that corner" [20:147].

John Rann, who was arrested six times for a robbery on the road, was a dangerous bandit. He would avoid conviction until 1774, when he robbed a chaplain and was hanged for this crime. Dating back to the turn of the sixteenth and seventeenth centuries, information comes about the Welsh bandit Twin Sion Cati (Thomas Jones). Legend has him as a Welsh Robin Hood who was supposed to steal from the rich and help the poor. He prowled in the vicinity of Cardiganshire. Robberies in the eighteenth century in England were a common phenomenon. Travellers were often assaulted on access roads to London. Robbers on foot were dangerous and most numerous, but the most audacious ones attacked on horseback, acting alone or in small groups. They attacked most often travellers in carriages or those travelling on horseback. The number of robbers increased at the beginning of the eighteenth century. The victims of the robbery were stagecoach passengers, mail cabs, carriages and wagons of farmers returning from the fair. Criminals armed with pistols wore masks. Their cry "Stand up and deliver" usually worked, and travellers under the blackmail of firearms gave away money and valuables without resistance [6].

In the 1820s, banditry had their high noon in Italy. A young travel writer Charles Macfarlane, wandering through Abruzzi, described in the form of an interview the fate of one of the most dangerous bandits at that time named Lupo, nicknamed "Passo di Lupo" (Step of the Wolf). At that time, the area was part of the Kingdom of the Two Sicilies and was under the rule of the Bourbon dynasty. Passo belonged to a gang of outlaws called Vardarelli, prowling the Ponte di Bovino, in a mountain range about thirty miles from his home in Monte Gargano. Bandits robbed travellers in Apulia, crossed the Mountains of Basilicata and ventured into other provinces plundering with impunity [21:17].

However, Eric Hobsbawm writes in his study on bandits that the career of bandits is short because it is risky and usually only two years pass when a robber is captured and punished or is forced to lead a lawful life [22:34-45].

However, the number of gangs and their audacity was so great that, in the face of the weakness of the local police and the sluggishness in capturing and judging bandits, especially rural areas of the country were very vulnerable to banditry. The police and authorities were unable to ensure safety on the roads of the Kingdom of the Two Sicilies. Then, not wanting to get into bloody skirmishes with bandits, King Ferdinand was persuaded to grant a pardon to all bandits who wanted to take advantage of the amnesty, and Passo was one of those who took advantage of this opportunity. 
This problem with banditry in Italy existed until the Second World War. The last Sicilian bandit was Salvatore Giuliano. He was very brash and even attacked the police. His fame was a problem for the authorities and the police. Fight against him was waged through and through; at various times the bandit was pursued by 2,000 policemen and soldiers. He was eventually killed in 1950. A historian Eric Hobsbawm described Salvatore Giuliano as the last of the folk bandits à la Robin Hood and the first whose activities were reported in real time by the contemporary mass media [23:12].

Travelling around Spain in the 1840s, T. Gautier warns that peregrination across Spain was a risky undertaking, apart from many inconveniences of travel: "there are rebels, innkeeper thieves, scoundrels and miscreants whose honesty was determined by the number of rifles on your part. Danger surrounds you, overtakes you, follows you; from everywhere you hear only terrible and mysterious stories. Yesterday the bandits had their supper in this hamlet. The robbers seized and abducted a convoy into the mountains to obtain a ransom. Pallilos lurk in the place through which you have to pass. There is certainly a lot of exaggeration in all this; and yet, even if you were the greatest sceptics, you have to believe, since at every crossroads of the road you can see wooden crosses with inscriptions such as: Aquimataron a un hombre (here a man was killed), Aquimurio de mano irada (here he died a violent death) [13:204-205].

Mączak writes that robbery often took on the character of extortion, tolls collected from visitors and it was not in the interest of robbers to kill travellers who did not resist. In Crete, the robbery was so well organized that if one gang found a pilgrim to lack valuable items, they then supplied him with a stamped piece of clay so that he could avoid being searched by the next. In the 12th-13th centuries, the traveller was exposed to a large number of all kinds of tolls. Often, various mountebanks forced travellers to pay for crossing the river in a ford or passage or a bridge. A fee was charged at the passes, before entering the stronghold or in any other place without a significant reason. Travellers tried to avoid places of exorbitant fees, barriers of greedy masters and places overrun by marauding robbers. Especially travellers-tourists and merchants going to the Pyrenean Peninsula had to reckon with great trouble. Sometimes the duty collection was so high that it ruined travellers. However, already in the Carolingian era, princes, especially in the Alps, tried to take care of the safety of mountain pass crossings, because the officially collected customs duties brought them considerable income [24:24].

In the nineteenth century, in the United States, an intensification of bandit attacks on train passengers was noted. Huge areas, the development of rail communication and especially the inability to provide protection to travellers by local security services, all these made robbery easy. In the years 1840-1900, public order was guarded by a "watchman" who was the guardi-an of order. However, the recruitment of officers took place in a random way and the candidates were taught the police profession by older experienced colleagues [25:36].

One of the most spectacular robberies of train travellers was the robbery by the bandit Jesse James on a train in Iowa. His gang stopped a moving train. On 21 July, 1873, near Adair, Iowa, James and his gang comrades damaged a rail section and then, as the train approached, used a rope to remove the rails, causing the locomotive to derail. As a result of the derailment of the train, the driver was killed and one of the passengers was seriously injured. Then two masked robbers entered the rail cars and found a safe belonging to the US Express Company in which they found only $\$ 2,000$, then robbed the passengers of the train. 


\section{HIGHLANDERS AND ROBBERS IN OLD POLAND}

Nineteenth-century historian Józef Szujski, touching on the problem of dangers in the heyday of the Middle Ages in Poland, writes: "Rape, robbery and murder are an ordinary thing, poisoning prowl violently in the thirteenth century. The spirit of a good farm turns into a spirit of rip-off and waste. [...] This is time of crime and Christian virtues, blasphemies and inspirations" [26]. However, as the sources indicate, robberies and deprivation of life were much rarer than common thefts, and Poland could be considered a country of relative peace. Długosz in History of Poland ${ }^{2}$ writes that the growth of robberies and their impunity in the Kingdom of Poland intensified especially during the interregnum periods. Jan Długosz recalls that robberies boomed during the times of Prince Władysław Łokietek and blames him for his indulgence towards the perpetrators of looting, villains and robbers, pointing out that "Prince Władysław, involved in romances, led a promiscuous life at that time" [27].

The most notorious robber in Poland, according to records from the mid-fifteenth century, was the knight Jan of Czerna, burgrave of Bolkov, who owed his position to the Czech king George of Poděbrady, in 1463. He carried out numerous robberies on travellers, mainly towns-people travelling south to Bohemia. The burgrave's robberies resulted in the conclusion of an alliance of townspeople from Wrocław and Świdnica to fight the robber. The townspeople of the two towns in 1468 organized a joint punitive expedition and successfully attacked the robber's castle with cannons. Jan of Czerna was captured alive and out of respect for his noble state, the townspeople hanged him in spurs [28].

S. Milewski cites figures of robbery crimes: during the reign of King Sigismund I in the years 1506-1509, robbers committed 566 murders in houses and on the roads of Poland (without the Mazovian land and Bełskie Province). The largest number of robberies occurred in Kraków Province - 169, and the Ruthenian Province - 145. A few decades later, during the reign of Sigismund II Augustus, 308 robberies were recorded and their growth, as many as 94 took place in Kraków Province [12:50].

Jan Kracik and Michał Rożek in their book Hultaje, złoczyńcy, wszetecznice $w$ dawnym Krakowie give examples of robberies and assaults in older Krakow and the surrounding area. In 1568, a group of thugs murdered travellers on the roads near Krakow; in 1664, municipal soldiers recruited from among Wieliczka salt-miners defended the suburb of Kraków called Kazimierz against a raid of looters; two of defenders were killed. In 1688 news spread about bands robbing manors and vicarages in the quarter of Podgórze; Kazimierz burghers kept guards days and nights for defence [29:99-100].

Not only better-off merchants and travellers were robbed on the roads near Krakow. Likewise, the bandits did not show contempt for peasant bundles, especially as these were no sweat to steal. In 1676, two small, degenerate nobles, Jan Gołąbek-Radwański and Stanisław Brachowski, found robbery on road from Ojców to Liszki an easy way to earn their living. They plundered merchants, craftsmen and peasants going and returning from the fair. The bandits were ruthless as not only did they rob their victims, but also committed several murders. In the end, they were captured, tortured and finally executed [29:100].

In the Polish lands, the Raubritters were particularly troublesome in Silesia (both Lower and Upper). The practice of knights-robbers developed after the Hussite wars in the fifteenth century, i.e. during the period of political and legal chaos. One of the most notorious Silesian bandits was the legendary Black Krzysztof from Olszanica near Złotoryja. In 1500-1512 this knight disturbed travellers on the roads, gaining ill reputation from great cruelty, not only robbing merchants, burghers and knights, but often after robbing

2 Annals or Chronicles of the famous Kingdom of Poland is one of the most important sources of medieval Polish history. The author of the annals, Jan Długosz, described the history of Poland in 12 books, from the legendary beginning of the Piast state up to 1480. 
them he would mete out a cruel death or wounds. After several years of unpunished robberies, however, he was captured and executed in Legnica. Prince Rogatka was also a degenerate knight robber. The problem of ma-rauding knights-robbers, mainly in Great Poland and Silesia, was solved thanks to the swift ac-tions of Henry the Bearded and Henry II the Pious.

Older Poland was a country of impassable forests, hence probably many legends and stories were the inspiration for Adam Mickiewicz to write "Dad's Return". The content of the poem presents a dramatic picture of the experiences associated with the dangers of the journey: the merchant set off on the road, when he approaches the house, his children greet him. He dismisses the servants and decides to return home on foot with the children. However, all of a sudden, dangerous armed robbers show up. The father wanted to implore them to save his and his children's life and was minded to give up all his property. Eventually, as a result of begging and prayers, the robbers abandon the robbery and allow everyone to return home freely [30].

In 1661 , most likely somewhere in the middle of nowhere robbers assaulted the outstanding Dutch painter Pieter Danckerts de Rij, the court artist of King Ladislaus IV of Poland. Danckerts was reported to die after two days as a result of the sustained injuries; yet before his death he managed to draw images of bandits who were soon captured and immediately execut-ed.

However, the safety of travellers in Poland compared to other European countries was high. S. Milewski in his book $W$ świecie występku i zbrodni quotes the opinion of the German lawyer, historian and traveller Johann Erich Binter, travelling around Poland at the beginning of the eighteenth century, on the safety of travel: "Irrespective of whether it is day or night, one travels in Poland very safely: several thousand ducats are carried by one man back and forth around the country, and even across the borders; often significant sums are entrusted to quite unknown coachmen from distant Polish provinces, and no one has yet heard that they were sto-len or robbed. In general, Poles are a nation too goodhearted and too calm to commit such crimes" [12:48], [31:338].

This opinion is confirmed by the Livonian Fryderyk Schultz, although reluctant to the Polish, passing through the Polish lands twice during the four-year Sejm and the third time in 1793, he give advice to take the way not through Prussia, but through Poland, where the post offices are faster and the roads are completely safe. At the same time, he was sure that neither he nor any of his many acquaintances, travelling around Poland, had ever seen anything suspicious in the darkest forests, even at night [31].

Also, according to the historian of administration Feliks Konieczny, Poland was relative-ly safe compared to other countries of Europe at that time. Coxe, a professor at the University of Cambridge, who travelled around Poland in 1779, accompanied by Lord Herbert, stated that, despite the poverty of the rural people, he had never lost anything during the entire journey, although they often left the carriage outside for the night without keeping an eye on it. In order to get to know the country and the people more thoroughly, they travelled by post coaches, spent the night in taverns, arranged meals by peasant bonfires, and never suffered any adventure or loss. Then, having crossed the borders of the Russian state, they left a servant in a carriage for the night and after each night they were found to have some kind of theft perpetrated [31:338].

However, not all the outskirts of the Republic of Poland were equally safe. At the turn of the eighteenth and nineteenth centuries particularly dangerous were the routes in the eastern borderlands of the Republic of Poland. J. Kitowicz in Opis obyczajów za panowania 
Augusta III writes: "Public roads were also frequented by the Haidamaka outfits; in the valley, sneaking not far from the road, they would keep an eye on the dust which in that greasy soil behind every rider rises high up. They were therefore mindful of the size of the dust: if they guessed out that by the size of dust a small convoy was approaching or even someone unescorted, they would fall on him, strip him of everything he had, and having beaten the victim with spear poles, his back, in a shirt alone they would let him go $[\ldots]^{\prime \prime}[32: 333]$.

Despite relative safety, organized gangs prowled various parts of the country. One of the most spectacular attacks in former Poland was recorded in 1787 . The victim was the magnate Szczęsny Potocki, and several carts of belongings, among the valuable items there were jewels worth 20,000 ducats and 3,000 ducats in cash, which fell prey to the robbers [12:48].

Mountain robbery was a common phenomenon, mainly in the Carpathian region, in the foothills of the Beskid Mountains and the Tatra Mountains. In the Polish Highlands there were packs of robbers called "societies"; in the Russian Subcarpathian region the "hoodlums" were engaged in robber craftsmanship. The greatest intensification of robbery in these areas took place at the turn of the seventeenth and eighteenth centuries. Robbers also prowled on the forest routes of the Beskid Sądecki, lived on the sidelines in deserted houses, huts, or went to the mountains to hiding places in rock caves and chasms. Most robbers originated from among the rural poor, although there were also representatives of the impoverished nobility. The latter often became the leaders of bands of 10-20 robbers. They were tempted by the spoils relatively easily accessible on the trade routes leading from Poland to Hungary. Although robbery ensured rapid enrichment, rarely did a robbery career last long. Often, after just a few robberies, the villain was shackled, later he faced a trial, torture and most often gruesome death (quartering alive, breaking with a wheel, driving onto a stake, hanging on a hook stuck in his ribs, hanging on a stake, burning at the stake). In Muszyna in 1664, Prokop Kropka, hanged alive by the rib, was petering out in agony. The Muszyna court became too well known for its harsh sentences, in the years 1647-1765 sentencing to death 21 robbers ( 9 to quartering, 3 to being woven into a circle, 1 to be put on a stake, 4 to hanging, 3 to beheading with a sword). The execution of the con-victs took place on a hill under the gallows [33:5-13]. In Poland, the Polish nobility fought against robbery, but to no avail. The Austrian authorities put an end to the practice only in the nineteenth century [34:229].

\section{PEREGRINATIONS AND TRAUMATIC EXPERIENCES OF POLISH TRAVELLERS}

In the old Poland, despite various doubts and warnings against sending young people on foreign trips, peregrinations had become a standard for high-born people. Stanisław Orzechowski, a biographer of the Crown Hetman Jan Tarnowski, wrote: "Believe me, whoever wants to be like this must needs see many things, must needs know the world" [35:688].

Mikołaj Rej and Andrzej Frycz Modrzewski encouraged foreign travel. In Polish memoir literature dating back from the fifteenth century, numerous references to the dangers of travel can be found. Jan Goryński, the author of Peregrynacje do Ziemi Świętej [36:263289] describes the unpleasant and frightening experience he got from the guards who were supposed to protect him but turned out to be very dangerous; they "bled those under their care of money rather than protected them" [37:22].

In the memoirs describing his peregrinations, Michał Krzysztof Radziwiłł the Orphan gives an interesting description of the event that he and his companions experienced during 
the return journey from the Holy Land through the Italian coast of the Adriatic Sea to Poland. Wandering Radziwiłł and five of his servants were attacked near the city of Piscary. The prince himself and his servants were deceived and plundered without pardon. Only the prince's chest, which fell prey to banditti, was quite a spoil, because there were two hundred sequins, two hundred scuds, Turkish knives wonderfully framed, precious stones and other gold objects [37:96], [16:184].

Another adventure is described by the same Radziwiłł the Orphan in the Peregrinations to the Holy Land and Egypt in the eighties of the sixteenth century ${ }^{3}$. The event took place in Heliopolis, a city located in northern Palestine on the eastern slopes of the Lebanese Mountains on the then route from Trypoli to Damascus. Radziwiłł the Orphan mentions robberies and the dangers of travel [37:40, 42-43,56 ].

Radziwiłł the Orphan learned from a trip to the Holy Land, and this lesson that he had learnt was that Arabs extort money more from Turks than from Christians and that in Egypt merchants are safe for the Turks have great benefit from this [37:130].

The fact that foreign travel can have a bad impact on the health and minds of young people was well known in old Poland. Many warnings were heard at magnate courts. Jakub Sobieski, father of Jan III Sobieski, says about travelling Poles that "harsh is their life, who as calves come to someone else's land and leave it as oxen" [38:247]. Hetman Stanisław Żółkiewski also advises his wife not to send her son abroad as from there he will not return with anything good.

Another danger was lying in wait for Polish travellers-tourists - other Poles. Jakub Sobieski commands his sons (1st half of the seventeenth century) Mark and Jan to avoid their compatriots when travelling and abroad. The Bełsk voivode voices his warning in instructions to his sons, under the threat of paternal disfavour: "If it comes to conversation with our Poles, I already beseech you with fatherly love for God sake, I order and enchant you under my bless-ing to act as carefully as possible, and plead to God for it, that as few Poles as possible will there be where you will stand" (Sobieski justifies this prohibition with the volatility of Poles, gossip, jealousy, waste, etc.) [38:258].

\section{DEFENCES}

In ancient times, robbery on the roads was so common that some municipalities were forced to establish special offices to combat robbers. In order to fight crime, legion outposts in the provinces organised large-scale manhunts, which, however, only partially eliminated the threat.

In the early Middle Ages, among the punishments, there was also a bizarre custom of kynophoria, consisting in forcing the convict to carry a live dog on his back from one German province to another. This punishment was introduced in 9th century by Charlemagne and was applied only to men from the aristocracy (the nobility carried a cat) who were accused of robbery. The size of the dog being carried (the size of the disgrace) was proportional to the punishment. This law was applied especially during the reign of Otto I (936-973).

The concept of mir (inner peace) was introduced into the law in the Middle Ages. One of the types of mir was the local mir-including, among others, the road. The legal system in-creased penalties for so-called private crimes, which included petty and large larceny, robbery and assault. Villains once captured, if they were not proven to have perpetrated

3 Mikołaj Krzysztof Radziwiłłt Orphan set off on a journey to the Holy Land on 16 September 1582 and happily returned to Poland on 29 May 1584 
major crimes, were stigmatised with their fingers or hands cut off, likewise their ears or part of them at best. Travellers were to beware of those so stigmatised.

In the eleventh century, the economic role of merchants increased, and its representatives became the richest stratum of the urban community. The need to protect material goods and improve travel safety prompted merchants to counteract marauding bands of robbers on the roads. For this purpose, guilds were established, which were associations of a defensive and social nature at the same time. Guild members jointly and severally bore the costs of organising travel, gathering goods and their safety, which was aimed at spreading the risks associated with trade to guild members.

From the tenth centuries onwards, pilgrimages from Western Europe to the Holy Land were no longer exceptional. Muslims did not actually hinder this movement, even when wealthy travellers took an armed detachment with them to protect themselves from the thugs. However, pilgrims going on the road were informed about frequent cases of attacks on Christians in the Holy Land. Hence, when in 1119 in Jerusalem two French knights Hugh de Payns (the first Grand Master) and Gottfried de Saint-Omer founded the Order, it was hoped that it would serve the purpose of protecting places connected with the life of Christ, as well as ensuring safety on the roads, mainly with a view to protecting pilgrims against Saracen robbers.

Wealthy travellers could count on escort services provided by mercenaries. Mercenaries escorting travellers in the Franconian countries were called cottereaux, as well as "adventurers", "foreigners" because they were most often Brabants or Aragonese. Their armament consisted of long knives. Many of them also came from sparsely populated lands as well as from the poor deprived of their own land originating from the suburbs of Dutch cities. They hired themselves seasonally to serve in escorting transports of merchant wagons [39:105-106].

In order to avoid seizures and material losses, a kind of camouflage was used. While travelling without a proper escort, it was important not to brag about wealth. For this reason the comfort of travel was often abandoned, and travellers satisfied themselves with modest living conditions. Some were so cautious that they sold their mount, continuing on foot in modest disguise. This is how Fynes Morysom carried out part of his journey through Europe (from Stras-bourg to Paris). Camouflage was also commonly used by others. A. Mączak in the book Życie codzienne w podróżach po Europie $w$ XVI i XVII w. writes that Bartłomiej Sastrow travelling mostly on foot as an experienced traveller-tourist: "sewed gold in the collar of his shirt, a valuable chain in his trousers. He didn't carry much baggage: a shirt and a manuscript of his deceased brother's poems, a bundle on his shoulder, a rapier at his side and a rosary - all to look like a Catholic soldier rushing to a meeting. After some time, however, this turned out to be risky and Sastrow successfully began to pretend to be mute" [16:185].

An anonymous Pole and at the same time a tourist of 1595 leaves an interesting literary account in the form of Diariusz peregrynacji włoskiej, hiszpańskiej i portugalskiej [37:130], in which he describes the vicissitudes with bandits, as he used a trick when they told him of bandits lurking on the road. The traveller headed towards a village called Spaccafurno. He walked on foot because of the news of robbers, and he was refused a horse when he asked for it. On the way, he was attacked and searched by robbers who found nothing on him, and having considered him poor, even helped him with alms. He later confessed with satisfaction that he had out-witted the thugs because he had 80 red "Hungarian kreuz ducats" hidden in his shoes. He said that on that day he had walked 32 Italian miles [37:130]. 
Thomas Coryat, who travelled at the beginning of the sixteenth century, also defended himself with a trick. The incident took place in the vicinity of Baden. When two thugs approached Coryat, who was dressed as a poor wanderer, he humbly took off his hat and then, stretching out his hand, suggestively asked for alms. This ploy turned out to be effective and the thugs, who were confused, not only did not attack the wanderer, but also gave him a small sum, which was enough for him for half a dinner [16:188]. Tricks were probably an effective weapon, mainly where the traveller faced the numerical superiority of the aggressor. Where one was threatened by an attack of one or two assaulters, a welltrained in fencing and hand-to-hand combat person had a chance to get himself out of oppression with a defensive hand.

The ability to fight hand-to-hand has been the basis of individual defence for centuries, and it was particularly important in times of wars, unrest, riots, and threats of robbery and looting. In the Middle Ages, the art of hand-to-hand combat belonged to the main seven knightly arts - „Sieben Behendigkeiten der Ritter” - which prepared a knight for battle. Although the cold steel was a symbol of nobility, the most effective weapon of the traveller was the knife. Knowledge of the knife fighting technique could save the traveller's life both in the town back-street, in an inn, and when he was attacked on the road. The knife could be used in a secretive way. It was easier to carry on the go than an epée or a firearm. However, where gangs were numerous and well-organised, the attempt at resistance could have tragic consequences. Among the villains, most often there were ordinary miscreants, but during the war one could often come across well-armed and trained soldiers who were ruthless in battle. Roger Ascham, a Cambridge scholar, visiting the Netherlands and Germany in the mid-sixteenth century, observed that the forests near Cologne and Aachen were full of well-armed villains. In this situation, those who could afford it hired an escort. Fear of bandits led travellers to ally in larger groups. This was intentional, and the escort cost less at the time. In the sixteenth and seventeenth centuries, in the territory of a large part of Germany as well as the southern Netherlands, it was possible to hire a detachment of soldiers as escorts to pass a certain section of the route. And since there was a fight somewhere almost continuously, it was not difficult to find a professional soldier either. In the times of wars waged at a laze pace: "In the fortresses, soldiers got engaged in trade, crafts, cultivated gardens. The Swiss papal guards out of service acted as guides on the «mirabilia» of the Eternal City; individual soldiers and entire units in their free time sought profitable employ-ment" [16:186].

Wealthy travellers set off with their own escort or hired professional soldiers. If they were also well-connected personalities, having family affinities with the ruling courts of Europe, then, even in times of great unrest, they could travel relatively safely. When in the first quarter of the seventeenth century, Prince Władysław Waza went on a trip to the countries of Western Europe (1624-1625), he was accompanied by a 50-person procession. The trip was well organized. The departure of the prince was preceded by letters of recommendation to important per-sonalities of the countries through which the procession was to pass. Where it was particularly dangerous, local notables on their own initiative took care to increase the escort. This was the case during the prince's stay in Würzburg where the local bishop provided him with protection by putting 30 soldiers at his disposal for further travel [33:129].

It was good to have a significant person in the area of the planned route as a patron or a guide. Stanisław Pac, a participant of the aforementioned trip of Prince Władysław, and at the same time the royal secretary of Sigismund II, recalls one of the incidents during the trip to Brussels. When he went from Kolno to the back of Prince Władysław to the Archduchess Infante along the route, the journey was dangerous. Fortunately, on the way he was accompanied by conte Ernesto a Linden In Reken, whom the Prince had sent with him earlier, secretly 
going with the convoy on his way. Conte Ernesto a Linden In Reken knew well the route of travel and these areas, because he had his possessions there, so in his company he travelled safely, because if it were not for his company, he would have to have a large escort. He also reported that during the trip, he watched the lurking robbers along the road. However, seeing the well-known conte Ernest and Linden In Reken, they withheld from the attack. If he had driven alone, he would certainly have been a victim of their robbery. [33:147-148].

Only a few could count on such an organized trip in terms of safety. The peregrinations of the elites were well planned and the organizers who were in their service had the necessary knowledge in the field of threats and travel experience. At the same time, they also had large financial resources and organizational capabilities. During Władysław Waza's journey, Stanisław Pac took care of his safety. When in September 1624 the prince was to go from Brussels to Namur, having obtained from the governor of Maastricht confidential information about a planned attack on his retinue by Dutch soldiers, he used a trick, changed the route and went to Diest by another road. However, the governor of Maastricht was cautious, hearing about ru-mours that 500 Dutch cavalry intended to ambush the Prince, strengthened his retinue with a hundred cavalry and as many infantrymen [33:157-159].

A fast horse could also be a good means of hasty retreat from robbers, and such was an excellent defender butcher dog Rottweiler, too. This dog had been bred by Roman legions in the town of Rottweil and bred there initially by butchers. When its extraordinary defensive qualities were recognized, it served wandering merchants as a means of defence against thieves and robbers attacking merchants' wagons. Merchants highly valued this breed and had a lot of confidence in them. When travelling, fearing looting, they would often tie purses of money to their dogs' necks, in order to secure their property. The fearless and formidable Rottweiler along the route and in the thickets of the forest was unreachable to the robbers [17:147-148] .

In Europe, fight against banditry on the roads has been carried out for centuries with a varying degrees of success. In the fifteenth century, René of Anjou, Duke of Lorraine, Anjou, King of Naples and Count of Provence, made efforts to ensure the safety of those travelling around his estates in southern France by ordering court officials to capture anyone who violated the safety of travellers. Soon, two dangerous robbers, Wilhelm Goy, called Maltostens ("doing evil everywhere") and Peter Archilion, were tracked down and imprisoned. The investigation was entrusted to an apt judge Rajmond Tesseyre. The course of the trial is known thanks to the notes drawn up by the notary Jan Stariti. When the lengthy interrogations did not bring results, the judge ordered torture, which was not used, because when Maltostens saw the instruments of torment, he began to testify revealing that he had acted together with another bandit Peter Mar-chion and others. He also confessed to the murder in the Boissiére Gorge of a 25-year-old young man, from whom they robbed 16 gold coins [40:21-23, 46-50]. Peter Archilon was also charged by another captured bandit, Wilhelm Breton, who admitted to assaulting a young student and robbing him for the sum of 40 pieces of gold. When the judge, impatient with the course of the trial, ordered torture, the mere sight of the tools caused Archilon's "sincere confessions". The bandit revealed that he belonged to a gang of 20 robbers divided into packs attacking travellers on the roads of Provence. The gang joined once or twice a year to split the loot. Despite pleading guilty, the judges' sentence was severe, though not very cruel, Maltostens and Archilon were hanged on the scaffold without torments.

4 The story of Friedrich Louis Dobermann, who is considered the father of the Doberman breed, is also known. Dobermann in the nineteenth century was a municipal official in the municipality of Apollo, he served as a manager of municipal real estate. He was also a city dog catcher and a tax collector. For this reason, he often had to travel long distances on horseback with a purse full of communal money. For fear of robbery, he came up with the idea of creating a dog, through appropriate crosses, which could become its protector in a critical situation, just like a Rottweiler dog. Soon dogs from the Dobermann kennel gained popularity throughout Thuringia, then in Germany, a little later throughout Europe. 
To a large extent, probably also the safety of travellers prompted representatives of 63 Hanseatic cities to adopt in 1557 during the general congress in Lübeck a treaty that guaranteed, among others, joint action against enemies and protection of trade routes. The document was delivered and sealed by four cities: Braunschweig, Gdańsk, Cologne and Lübeck. In Poland, more than two and a half centuries earlier, the cities under German law Poznań, Gniezno, Pyzdry and Kalisz formed a similar confederation, obtaining from King Władysław Łokietek the privilege of punishing robbers and assaulters with death. The right of punishment was ex-tended even to persons of the noble state.

Although all over Europe there were attempts to fight the scourge of robbers, the effect of these actions was small. In the Papal State, police decrees against robbers only frightened potential travellers. Advice for travelling tourists was included by Geogia Loysia in the instruction of 1600. He advises that in a foreign country, as precautions, they should not criticise customs or religion. They should also lie down for safety during the day in hay or in the grass. In inns, he recommended tourists to look for clean places, to examine the location of the room for the solidity of the bolts and doors [16: 194]. In 1613, the Magnate Zbigniew Osoliński, sending his son Jerzy abroad, ordered him to check the "safety of inns" in the Reich.

In the seventeenth and eighteenth centuries in France, the scourge of banditry reached considerable proportions. One of the most notorious bandits was Philip Guillery, a soldier of king Henry IV's troops. Philip Guillery and his two brothers formed a gang whose number reached 500 thugs. The gang prowled the roads, robbing and collecting tribute from travellers. After a few years, strong armed units were sent to the Area of Lower Poitou against the Guillery gang for pacification. The bandits were smashed; one of the brothers was killed; another was broken with a wheel, and Guillery himself escaped the chase, but was soon handed over and executed in La Rochelle.

In 1721, the rogue activity of another bandit of the notorious Cartouche was put to an end. This French villain organized a gang of former soldiers initially 200 strong, and at the peak of his activity he kept about 2,000 people under his command. The gang attacked stagecoaches, as well as private estates and places of trade. Cartouche became a symbol of the bandit's impu-nity, but was eventually captured and put on trial. In prison, the investigator subjected the Con-ciergerie to elaborate torture: he had him put on "laced-up boots" and then drove into his shave 8 iron wedges, and finally subjected him to breaking with a wheel. At the place of execution, in the face of death, he eventually managed to denounce his comrades. For eighteen hours there was a march of the thugs he had betrayed. Honest confessions, however, did not save the ban-dit's life. On Grevé Square, the executioner broke his bones with an iron hammer, then the body crushed on the wheel was fixed on top of a pole.

During the French Revolution, gangs of so-called "scorchers" and "carriages" prowled on the territory of France. The actions of the gangs were facilitated by the situation of chaos and anarchy during the Great Terror and the Directory. No route was safe, bandits robbed and tor-mented captured travellers. In this situation, at the beginning of 1801 the Consulate established criminal courts to judge cases of robbery [41:144]. Soon, the French government sent Jean Bon Saint-André to the Rhineland (which came under the French rule) with considerable forces to clear the Normandy territories of bands of plunderers. At that time, the famous bandit from the Rhine was Johannes Bückler called Schinderhannes ("John the Skinstripper"), who created a gang modelled on a real army, divided into independent corps. The actions of the troops brought the expected result, and soon Schinderhannes' gang was broken up and its members captured and put into the prisons of Koblenz and Cologne. Soon, the very chief Schinderhannes was 
also captured in the territory of France. During the investigation, prosecutors charged him with 65 crimes, including bloody slaughter. The verdict was a foregone conclusion, on 21 November 1803 Schinderhannes, one of the most dangerous bandits of his time, was beheaded on a scaf-fold.

In Poland, in the early Middle Ages, matters related to road safety were in the competence of the monarch, as well as voivodes and castellans. However, apprehension of the perpetrators of robberies mainly belonged to high royal officials. In the countryside, the duty to catch thugs was incumbent on the members of the territorial community called local settlements. Later, a watchman's office was introduced. At the end of the thirteenth and in the first half of the fourteenth century, in order to ensure safety on roads that were under threat especially by knights-robbers, the cities of Greater Poland and Silesia formed confederations, which even maintained armed troops. The fight against robbery on the roads was vigorously led by kings Władysław Łokietek and Kazimierz. At the end of the thirteenth century, initially in the prov-inces, and since the mid-fourteenth century, in the strongholds, the offices of starostas (heads of local communities) were established, who were to watch over security matters. In the fourteenth and fifteenth centuries, the prosecution of criminals threatening public peace ${ }^{5}$, and later on putting them before municipal courts was dealt with by the justiciaries (torturers). It was a police and judicial office, functioning during the period of formation of the office of the starosta in former Poland. The torturer not only prosecuted the road robbers regardless of their state affilition, but also investigated and judged, and then meted out punishments. The office known al-ready in the fourteenth century was liquidated when the police and judicial power passed into the hands of starostas. The office of the torturer was formally liquidated by Jogaila (Jagiełło) in 1388; however, in some areas, it was maintained until the end of the fifteenth century, then it was subordinated to the starosta between 15th and 16th centuries. The torturers acted only in Lesser Poland as officials subordinate to the king [42:210].

From the sixteenth century, starostas entrusted competences concerning security to their deputies. It also happened that if a starosta (his deputy) did not have enough militia under their command to fight a gang of robbers, he could gather the local nobility. Starostas in Poland until the 2nd half of the eighteenth century were the only permanent local police authority. In the seventeenth and the 1st half of the eighteenth century, when the danger of travel was particularly high, for example in the Subcarpathian region, starostas organised mercenary troops of the so-called harniks to combat robbery. Peasants were also forced to cooperate. An important role in ensuring safety on the roads of the former Republic of Poland was also played by the military forces of the Polish magnates. In the countryside, matters of order and security were entrusted to vogts (rural municipality administrators), who performed police duties with the help of officials under oath elected for a period of three years. In cities, the security services were subordinate to the mayor and the city council, and some cities maintained a large city militia. Sometimes police activities were taken over by burgraves who aided by house servants captured criminals (if they had any). According to the constitution of 1507, the burgrave was entrusted with guarding road safety and catching criminals [42:213].

But there were also those who although brought to justice, beat the charge. An example is a certain Samuel Łaszcz (1588-1649) - a nobleman, a well-known firebrand and a Lisowczyk rider, who organised bandit regiments subsisting on robberies. Łaszcz was sen-tenced to banishment 236 times and infamy 37 times. This robber, a petty noble, however, did not care much about court verdicts because, as a soldier he rose to fame in many wars, and was under the exclusive jurisdiction of the hetman and was protected by a kind of immunity. It was rumoured about Samuel Łaszcz that only creditors and a gypsy

5 Crimes are split into four magistrate articles: arson, robbery of a house, robbery on the road, rape of a woman 
musician did not leave him until his death.

\section{CONCLUSIONS}

Always, both in the most distant history and now, travel has been accompanied by danger. Nowadays, insecurity is becoming a basic barrier to tourist travel to high-risk areas. Threats on the road are of a difficult nature to predict, from the dangers caused by the forces of nature to the deadly threat resulting from human actions, most often with an intent to rob, but also against a political (terrorism), religious or national background. Despite the ongoing civilizational changes, including the extraordinary dynamics of cultural changes, the dangers of travel still show an analogy to the former days. The end of the nineteenth century was a borderline period, it marked the irretrievable end of primitive road banditry. At the beginning of the twentieth century, Karl Beadeker wrote in his guidebook: "Public safety in the vicinity of commonly visited Italy, Sicily and Sardinia is as significant as in the rest of Europe" [16:272]. At the same time, travellers were advised not to say where they were going and not to show off their wealth.

The development of safe communication, the emergence of strong state bodies in Europe with a developed system of security apparatus effectively limited and then eliminated the epicentres of high-risk areas, which does not mean the complete elimination of road banditry. Also today, information about attacks on tourists is coming from some regions of Europe, the mechanisms and methods are confusingly similar to those known from history.

\section{REFERENCES}

[1] Knebel HJ. Soziologische Strukturwandlungen im Modernen Tourismus. Stuttgart; 1960.

[2] Schudt L. Italienreisen im 17. und 18. Jahrhundert. Vienna; 1959.

[3] Kaczmarek J, Stasiak A, Włodarczyk B. Przestrzeń gościnna - kilka uwag o konkuren-cyjności regionów [Hospitable space - a few remarks on the competitiveness of regions], In: G. Gołembski (ed.). Turystyka jako czynnik wzrostu konkurencyjności regionów w dobie globalizacji. Poznań; 2008.

[4] Tuan Y-F. Przestrzeń i miejsce [Space and place]. Warszawa; 1987. Polish.

[5] Stasiak A. Bezpieczeństwo - niebezpieczeństwo w turystyce (kilka refleksji wprowadzających w zagadnienie) [Safety - danger in tourism (some reflections introducing the issue)], In: A. Stasiak, J. Śledzińska (ed.). Między swobodą a zakazem, czyli o bezpiecznym korzystaniu z przestrzeni turystycznej.Warszawa; 2017. Polish.

[6] Nature of crimes. https://www.bbc.co.uk/bitesize/guides/z2cqrwx/revision/8 [15.09.2021]

[7] Pastoureau M. Życie codzienne we Francji i Anglii w czasach rycerzy okrągłego stołu (XII-XIII w.) [Everyday life in France and England during the times of the knights of the round table (12th-13th centuries)]. Warszawa 1983. Polish.

[8] Aziz H. Understanding attacks on tourists in Egypt. Tourist Management. 1995;16.

[9] Somnez S., Tourism, terrorism, and political instability. Annals of Tourism Research. 1998;25:416-456.

[10] British Library. https://www.bl.uk/romantics-and-victorians/themes/crime-and-crime-fiction. [15.09.2021]

[11] Schnayder J. Podróże i turystyczne szlaki w starożytności [Travels and Tourist Routes in Antiquity]. Kraków 1968. Polish.

[12] Milewski S. W świecie występku i zbrodni. Z dziejów przestępczości i jej zwalczania [In the world of crime and crime. From the history of crime and fighting it]. Warszawa; 1996. Polish.

[13] Gautier L. La chevalerie. Paris; 1894.

[14] Luchaire A. La société française en temps de Philippe-Auguste, Paris; 1909.

[15] Huizinga J. Jesień średniowiecza [Autumn of the Middle Ages]. Warszawa; 1974. Polish.

[16] Mączak A. Życie codzienne w podróżach po Europie w XVI I XVII w. [Everyday life in travels around Europe in the 16th and 17th centuries]. Warszawa; 1980. Polish.

[17] Jowków J. Legendy Starej Płaniny [Legends of Stara Planina]. Warszawa; 1982. Polish.

[18] Goodall R. Time travel: the history of the Highwayman. https://theboar.org/2021/01/time-travel-the-history-of-thehighwayman [15.09.2021]

[19] Gautier T. Podróż do Hiszpanii [Journey to Spain]. Warszawa; 1979. Polish.

[20] Przyboś A, (elab.). Podróż królewicza Władysława Wazy do krajów Europy Zachodniej w latach 1624-1625 w świetle ówczesnych relacji [The journey of prince Władysław Vasa to the countries of Western Europe in the years 1624-1625 in the light of the then reports]. Kraków; 1977. Polish.

[21] Macfarlane Ch. Lives and Exploits of the Most Celebrated Banditti and Robbers of all Na-tions Philadelphia 1833.

[22] Hobsbawm EJ. Bandits. New York: Pantheon Books; 1981.

[23] Hobsbawm EJ. Robin Hood, New York; 1985. 
[24] Riché P. Życie codzienne w państwie Karola Wielkiego [Everyday Life in the State of Charlemagne]. Warszawa; 1979. Polish.

[25] Chappell AT. Police academy training: comparing across curricula. Policing: An International Journal of Police Strategies \& Management. 2008:31(1):36

[26] Szujski J. Dzieje Polski [History of Poland], Vol. I. Lwów; 1862. Polish.

[27] Annals or Chronicles of the Famous Kingdom of Poland, Books VII and VIII. Computer edition. www.zrodlahistoryczne. prv.pl

[28] Kunicki K, Ławecki T, Olchowik-Adamowska L. Śladami słynnych zbrodni [In the footsteps of famous crimes]. Lesko; 2011. Polish.

[29] Kracik J, Rożek M. Hultaje, złoczyńcy, wszetecznice w dawnym Krakowie [Rascals, villains, harlots in old Krakow] Kraków; 1986. Polish.

[30] Mickiewicz A. Powrót taty. Pani Twardowska [Dad's return. Mrs. Twardowska]. 2017. Polish.

[31] Konieczny F. Dzieje administracji w Polsce w zarysie [An outline of the history of administration in Poland]. Wilno; 1924. Polish.

[32] Kitowicz J. Opis obyczajów za panowania Augusta III [Description of the customs during the reign of August III] Wrocław; 1970. Polish.

[33] Przyboś K. Zbójnictwo karpackie [Carpathian robbery]. Almanach Muszyny; 2000. Polish.

[34] Ochmański W. Zbójnictwo Góralskie [Highlander robbery]. Warszawa 1950. Polish.

[35] Kot S. Polska złotego wieku wobec kultury zachodniej. Kultura staropolska [Poland of the golden age in the face of Western culture. Old Polish culture]. Kraków; 1932. Polish.

[36] Baranowski J. Prace Komisji do Badań nad Historią Literatury i Oświaty [Works of the Commission for Research on the History of Literature and Education], t. I. Warszawa; 1914. Polish.

[37] Antologia pamiętników polskich XVI w. [Anthology of Polish diaries of the 16th century]. Wrocław; 1966. Polish.

[38] Łoziński W. Życie polskie w dawnych wiekach [Polish life in the old centuries]. Kraków; 1978. Polish.

[39] Duby G. Bitwa pod Bouvines [Battle of Bouvines]. Warszawa; 1988. Polish.

[40] Gaspari A. Un crime en Provence au XV e, Paris; 1991.

[41] Dagen NL, editor. Największe procesy w historii świata [The greatest processes in the history of the world]. Wrocław; 1995. Polish.

[42] Góralski Z. Urzędy i godności w dawnej Polsce [Offices and dignities in old Poland]. Warszawa; 1998. Polish. 